\title{
Effect of space holder percent on the porosity biocompatibility of nano Ti foam by PM technique
}

\author{
M. A. Khater ${ }^{1}$, M. T. Elwakad ${ }^{2}$, O. El-kady ${ }^{3}$ and A. S. Eldesoky ${ }^{4 *}$ \\ ${ }^{1}$ Department of Biomedical Engineering, Faculty of Eng., Helwan Univ, Cairo, Egypt. \\ ${ }^{2}$ Faculty of Eng. \& Technology, Future Univ, 5th settlement, Cairo, Egypt. \\ ${ }^{3}$ Central Metallurgical Research and Development Institute (CMRDI), P.O. Box 87, Helwan, Cairo, Egypt. \\ ${ }^{4}$ Department of Biomedical Engineering, Higher Technological Institute, 10th of Ramadan, 228, Egypt.
}

*Corresponding author: E-mail: amal-eldesoky70@ hotmail.com, Tel: 01097884690

Received 15 April 2021

Revised 26 May 2021

Accepted for publication 18 June 2021

Published online 30 June 2021

\begin{abstract}
Powder metallurgy (PM) approach was utilized for the preparation of Ti porous material mixed mechanically with different percentages of sodium chloride salt from 10 to $40 \%$ with stirring speed $100 \mathrm{rpm}$ and ball to powder ratio 10:1 for milling time $24 \mathrm{~h}$. The $\mathrm{Ti}-\mathrm{NaCl}$ mixed samples were compacted under $600 \mathrm{Mpa}$, then sintered at $1450^{\circ} \mathrm{C}$ for 90 min in a vacuum furnace. The phase composition and microstructure of Ti samples are investigated through X-ray diffraction analysis and scanning electron microscope (SEM). All the prepared samples were characterized by measuring the porosity percentage, Vickers hardness, and compression strength. Microstructure indicated that porosity was found to increase with increasing salt percent while the highest hardness (380) and the compression strength $(45 \mathrm{MPa})$ were recorded for the lowest ratio of salt $(10 \% \mathrm{NaCl})$. Biocompatibility test was estimated for the prepared samples, which exhibited the high viability for cell with good growth of the life cells on the sample's surface, and low adhesion.
\end{abstract}

Keywords: Biocompatibility; Mechanical properties; Powder Metallurgy; Porous Titanium; Medical applications.

\section{Introduction}

The use of metals for health and healing stretching back since ancient times. The Eber's Papyrus was the first who had used the copper to iron to treat anaemia. Most drugs include metals such as zinc, lithium, gold \& platinum [1]. Meanwhile, metal alloys are used as biomaterials for a long periods of time such as (stainless steel, cobalt-chromium alloys, Titanium and its composites, Nickel-titanium alloys, zirconium alloys and niobium alloys) due to their composition and mechanical properties[2], low corrosion rate and surface properties. Furthermore, their excellent yield strength and highest biocompatibility with life cells and lower toxicity are noticeable $[3,4,5]$. Recent benefits could be easily found in metal foam that have a good advantages when it is compared with the non-metal foams, as it offers higher stiffness[6], strength to weight ratios and high impact energy absorption, They also have a great tolerance to both environmental conditions and temperature which are satisfied for medical applications $[7,8,9]$.Titanium is one of the most tough and durable metal foam which is a common material used for different kinds of medical applications especially as a medical implant for the replacement of a biological tissue. Consequently, this study aims at assess in vitro the influence of four pore percent of titanium samples on the new bone ingrowth. The samples are produced by means of a powder metallurgy. The primary objective of this investigation is to fabricate (Ti) with different percentages of porosity using $\mathrm{NaCl}$ as a space holder material by powder metallurgy technique. The profound impact of porosity on microstructure and mechanical properties of $\mathrm{Ti}$ powder for orthopaedic applications was considered.

\section{Materials and Methods}

Nano-titanium powder with $99.8 \%$ purity, 6-40 nm particle size, 4.5 density and molar mass of $47.9 \mathrm{~g} / \mathrm{mol}$ and $\mathrm{NaCl}$ salt powder of $2 \mu \mathrm{m}$ particle size and molar mass of $58.44 \mathrm{~g} / \mathrm{mol}$ and $2.16 \mathrm{~g} / \mathrm{cm}^{3}$ delivered from (NILCOO) were employed as the raw materials for ( $\mathrm{Ti}-$ $\mathrm{NaCl}$ ) preparation (Fig. 1a) Mixture of $\mathrm{Ti}$ and $\mathrm{Na}-\mathrm{Cl}$ with different ratios of $10,20,30$, and 40 wt. \% were 
prepared. In order to check the chemical composition and the morphology of the as received powders, X-Ray diffraction and scanning electron microscopy (SEM) were performed.

Pure Ti samples (12 $\mathrm{mm} \times 3 \mathrm{~mm})$ were prepared by powder metallurgy route. The mixtures were prepared by the mechanical milling using a ball mill machine with ball to powder ratio (10:1) and speed 100 $\mathrm{rpm}$ for $24 \mathrm{~h}$. To avoid the oxidation, argon gas was used during the mixing process. The prepared composite powders were compacted under pressure of $600 \mathrm{MPa}$. The samples were sintered at $1450^{\circ} \mathrm{C}$ for 90 $\mathrm{min}$ in a vacuum furnace. Fig.1 shows the heating process cycle with a heating rate of $5{ }^{\circ} \mathrm{C} / \mathrm{min}$. The mixture was heated up to $250{ }^{\circ} \mathrm{C}$ for $30 \mathrm{~min}$ to allow gases to evolve the leaving pores. The temperature was raised up to $1450^{\circ} \mathrm{C}$ for $90 \mathrm{~min}$ to complete the sintering process. Fig. 2 indicates a schematic diagram for the fabrication process of titanium foam using $\mathrm{NaCl}$ as a space holder by powder metallurgy method $[10,11]$.

For Microstructure investigations, discs with $10 \mathrm{~mm}$ thickness were cut, polished. Discs were immersed in a solution contains $95 \%$ ethanol and $5 \%$ nitric acid for $40 \mathrm{sec}$. then, they were dried. Optical microscope with model OPTIKA M-790, Italy was used for metallographic observations. The average size of $\mathrm{Ti}$ particles were measured using image analyzer AxioVision software.

\subsection{Physical Properties Measurements}

Density of the prepared samples were determined using Archimedes principal according to ASTM C $373-$ 72, 1984.Next equation is used [12].

$\gamma_{\text {Arch. }}=\frac{w_{\text {air }}}{\left(w_{\text {air }}-w_{\text {water }}\right)}(2) \times \frac{1}{\text { Ti density }} \cdots \cdots . .$.

Where, $\mathrm{W}_{\text {air }}$ and $\mathrm{W}_{\text {water }}$ represent the specimen weight in air and water, respectively. The results were compared with the theoretical density. The chemical composition and the phase structure were investigated by X-ray diffraction (XRD) on a Brukur advanced Xray diffractometer model D8 kristalloflex (Ni-filtered $\mathrm{Cu} \mathrm{Ka)}$.

\subsection{Mechanical properties}

The hardness of Ti foam samples were measured using Vickers tester model (Matsuzawa JAPAN) by applying $20 \mathrm{~kg}$ load for $15 \mathrm{sec}$ at room temperature. The tests were repeated for each sample five times and the hardness values were the average of the five readings.

The compression test was performed using universal testing machine according to ASTM at a strain of $0.01 / \mathrm{s}$. Compression tests were repeated three times at room temperature.

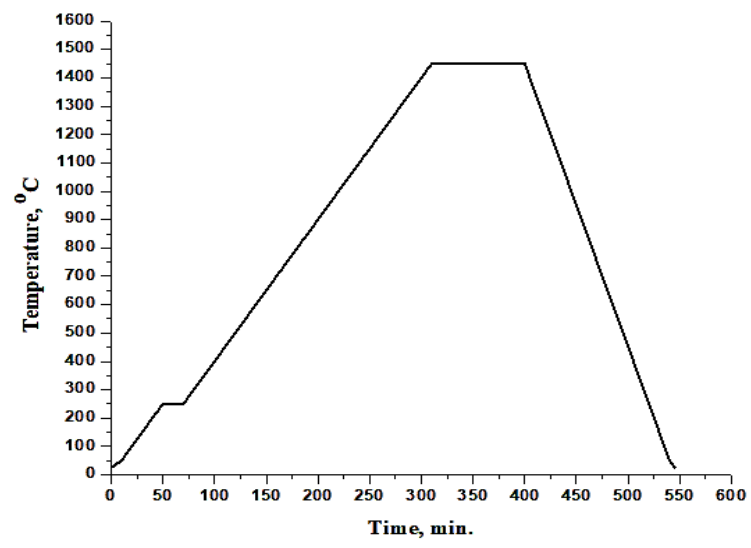

Fig. 1 Heating cycle of the sintering process for composite fabrication.

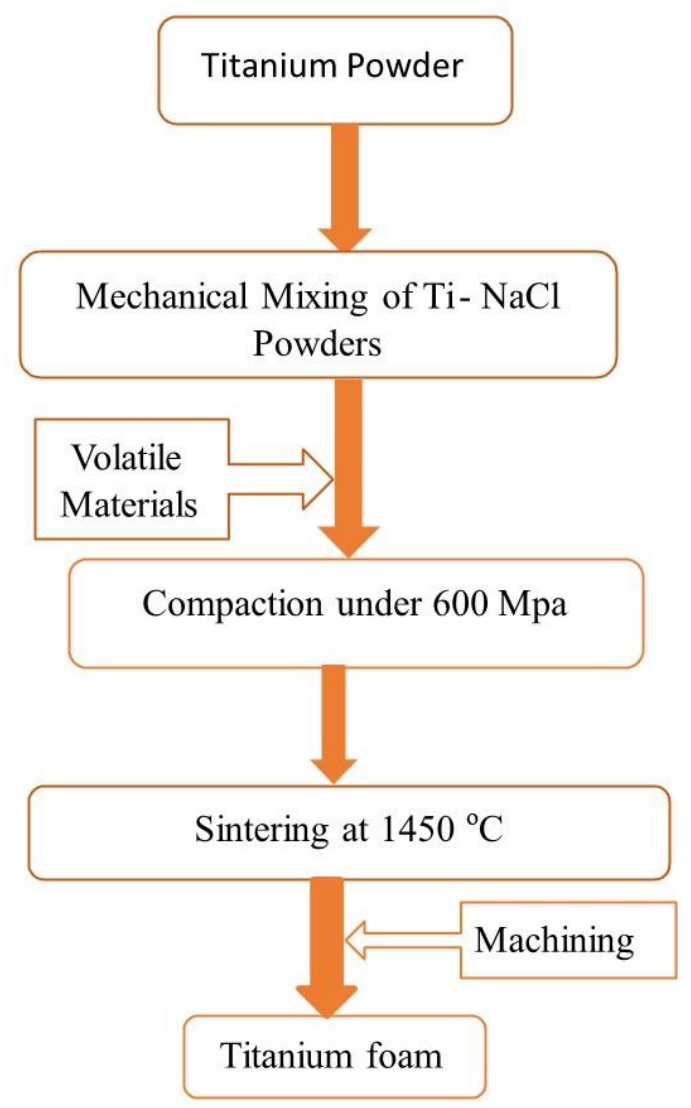

Fig. 2 Schematic diagram for preparation of Ti foam

\subsection{Biocompatibility Investigation}

\subsubsection{Cell cultures}

Normal cell line was provided by VACSERA-Egypt (tissue culture department). The cells cultured in RPMI 1640 medium with $10 \%$ fatal bovine serum (GIBCO, USA) and $1 \%$ penicillin- streptomycin (Invitrogen, USA) was examined. 
Cells incubated at $37^{\circ} \mathrm{C}$ in atmosphere humidified with $5 \% \mathrm{CO}_{2}$ (Joan-France) as advised by manufacturer instructions were accomplished. For survival and proliferation, cells were cultured in artificial medium [13]. The medium supports cell growth, $\mathrm{pH}$ and osmolality. It consisted of amino acids, vitamins, salts, glucose, and growth factors, and nutrients.

\subsubsection{Cytotoxicity and cell viability}

To measure the cell viability, cells were incubated with an indicator and the conversion was calculated. As the cells were alive, indicator would be consumed, or partially consumed. Normal cells were propagated in $75 \mathrm{~cm} 2$ cell culture according to Busser au et al., 1982. Cells were detached using trypsin solution $[0.25 \% \mathrm{w} / \mathrm{v}]$ and EDTA [0.05\% (v/v)] (GIBCO-USA) for five minutes. The cells were incubated by $2 \times 10^{5} \mathrm{cell} / \mathrm{ml}$ concentration in culture plates at $37^{\circ} \mathrm{C}$ for $24 \mathrm{~h}$. Fresh medium containing 2-fold serially diluted pomegranate peel extract PPE was added to cells. A day later, cells were washed using phosphate buffered-saline PBS and $50 \mu \mathrm{l}$ MTT $(0.5 \mathrm{mg} / \mathrm{ml}$ of 3-(4,5-dimethylthiazol2-Y1)2,5-iphenyltetrazolium-bromide)) was added. Formazan precipitates were solubilized using $50 \mathrm{ml}$ dimethyl sulfoxide (DMSO). For 4 hours' incubation period, light absorbance with $570 \mathrm{~nm}$ wavelength was realized using plate reader (ELX -800, Biotech- USA), viability percentage of cells was calculated:

Viability $\%=\frac{\text { mean OD }(\text { test dilution }) \times 100}{\text { mean } 0 D(\text { negative cell control })}$

Where OD is the optical density, $\mathrm{V}$ is the absorbance ratio of the tested samples to the absorbance of a reference one. It must be mentioned that the absorbance is proportional to the pathogen amount in sample.

\subsubsection{Morphology and Cell adhesion}

Scanning electronic microscope (SEM) was used to monitor cell proliferation. The images show the microstructure and the cell that success to attach on the sample surface and its growth. For adhesion test, a washing buffer composed of $0.1 \%$ BSA (Bovine serum albumin-a supplement protein) and blocking buffer$0.5 \%$ BSA in DMEM medium (Dulbecco's Modified Eagle Medium), Laminin-1 (10-12 mg/ml), crystal violet $(5 \mathrm{mg} / \mathrm{ml}$ in $2 \%$ Ethanol), $1 \%$ sodium dodecyl sulfate SDS (surfactant) and $4 \%$ paraformaldehyde was carried out.

Cells were cultured on samples for $24 \mathrm{~h}$ and the cell growth was calculated. After that, plate was coated with Laminin-1 for $1 \mathrm{~h}$, then washed with buffer twice, and blocked in $\mathrm{CO}_{2}$ incubator at $37{ }^{\circ} \mathrm{C}$ for $45-60$ minutes then the cells were counted [14].

To test cell-adhesion, the plate was shake by speed $2000 \mathrm{rpm}$ for 10-15 seconds, washed and fixed using
$4 \%$ paraformaldehyde. The stained plate was washed, turned upside-down, dried and read at $550 \mu \mathrm{m}[15,16]$.

\section{Results and Discussion}

\subsection{Samples characterization}

Fig. 3 depicts Ti powder was nearly spherical with some aggregations. Besides, the particle size of the powder was ranging from 6 to $40 \mathrm{~nm}$.

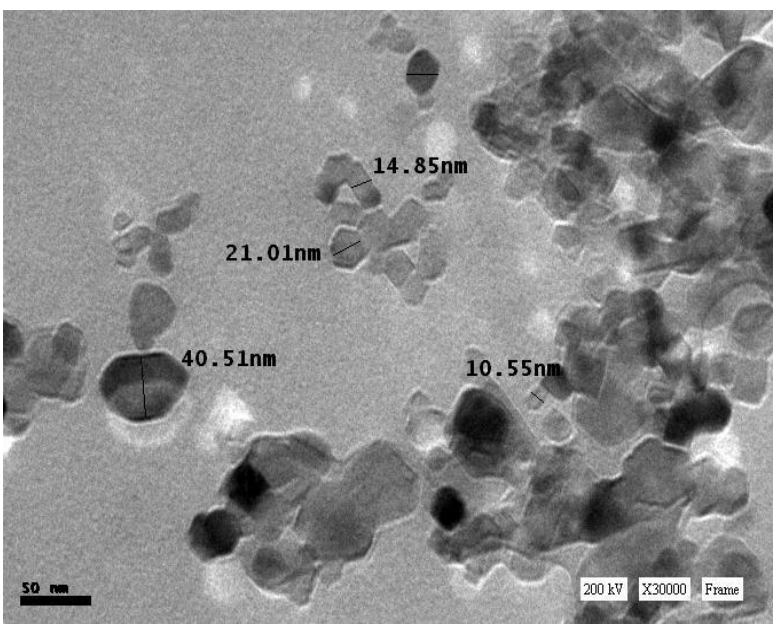

Fig. 3 TEM micrograph of the used nano Titanium powder.

\subsubsection{Density measurements}

The effect of $\mathrm{NaCl}, \%$ on the density and the porosity values were shown in Fig. 4(a, b). Clearly, increasing the sodium chloride salt , $\%$ as a space holder material was gradually decreased and then the porosity, \% was increased. This is imputed to the impact of the hollow $\mathrm{NaCl}$ particles called as micro balloons as light weight and inert. The presence of hollow particles such as $\mathrm{NaCl}$ results in the foam structure with low density.

The theoretical density is higher than that of the actual density for the sintered samples. The factors affecting the density of sintered samples were the compaction process, sintering temperature and time. [17].

Additionally, some agglomerations of the Ti with traces of salt may occur as the $\mathrm{NaCl}$ percent increasing. Accordingly, the microballons percent were increased causing the porosity ratio increased.

\subsubsection{Samples microstructure}

The SEM images of the fabricated samples show that a lamellar structure is formed. Increasing the ratio of $\mathrm{NaCl}$ salt, increases the porosity and lamellar forming. Some agglomerations of $\mathrm{Ti}$ takes place with high $\mathrm{NaCl}$ percentage which are 30 and 40 wt. \%. Fig.5 shows confirms the near densification of sintered samples. 
The pores are elongated with oval shape confirming the foam structure of Ti samples.

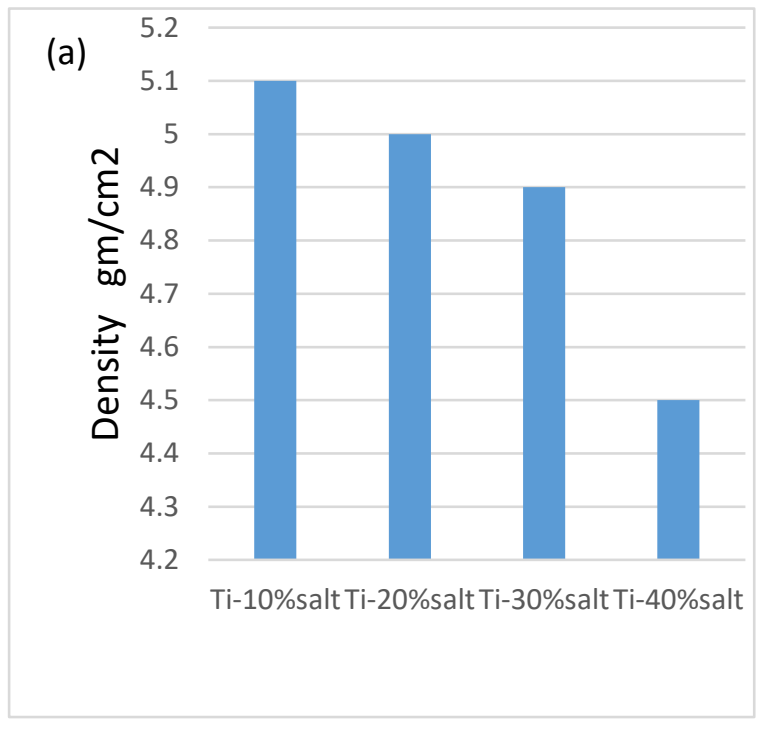

(b)

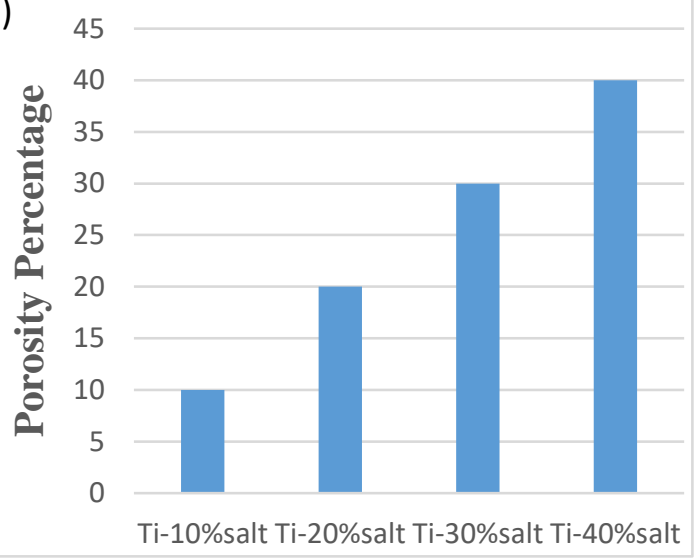

Fig. 4 (a) The effect of $\mathrm{NaCl}$ percentage on the density values, (b) on the porosity values.

Also, pores are interconnected which is suitable for cell growth, So the samples could be used for many tissue engineering applications [18,19]. Microstructure shows porosity with different ratio according to the space holder percent in which it increases by increasing the $\mathrm{NaCl}$ percentage which are confirmed from the density and porosity figures $4(a, b)$.

\subsection{Mechanical properties of porous Ti samples}

\subsubsection{Hardness test}

The effect of space holder $\mathrm{NaCl}$ percent and porosity on hardness of pure titanium are shown in Fig. 6. It shows that the addition of salt wt. \% to pure nano
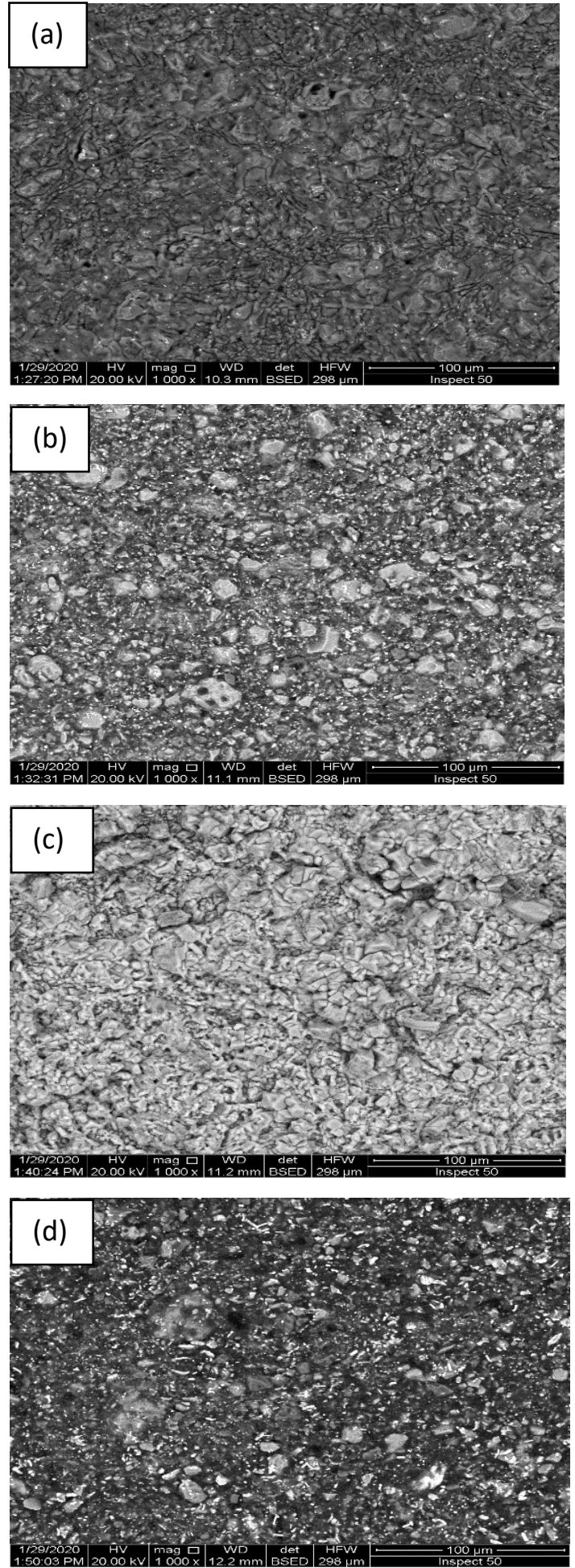

Fig. SEM images of samples: (a) $10 \%$ wt., (b) 20

$\%$ wt., (c) $30 \% \mathrm{wt}$, and (d) $40 \% \mathrm{wt}$.

titanium particles decreases the hardness from 380 (10\% salt) to 150 with percentage of $40 \%$. The hardness is decreased, due to the agglomerations of $\mathrm{Ti}$ and increases of salt ratio which increases the porosity. 
It is obvious that the hardness is still high compared to pure Ti without porosity. This result could be due to the nano-size of $\mathrm{Ti}$ and the mechanical milling process according to Hall-Petch equation [20]. The reduction of Ti particle size to more nano scale enhances the hardness values of the prepared samples. But the increasing in the porosity percentage decreases the hardness in which the hardness indicator depth is increased [21].

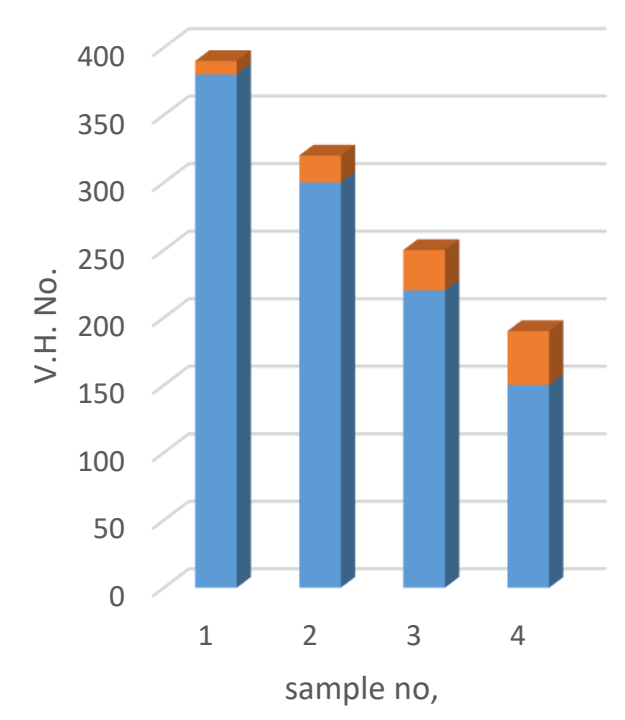

V.H. No. $\quad$ salt content Ratio

Fig. 6 Effect of the porosity on the hardness of the Ti foam samples.

\subsubsection{Compression test}

The effect of $\mathrm{NaCl}$ salt content and porosity on the compression of pure titanium are shown in Fig.7. As shown from the Fig., addition of salt to pure titanium decreases the compression from $45 \mathrm{MPa}(10 \%$ salt) to $25 \mathrm{MPa}$ for $(40 \% \mathrm{NaCl}$ salt $)$ due to the agglomerations of $\mathrm{Ti}$ and increases of salt ratio which causes an increasing of porosity.

It is found that with increasing porosity percentage by increasing $\mathrm{NaCl}$ content gradually, the compression strength decreases. This is may be attributed to increasing the pores in the samples, in which the pore is nuclei for crack initiation and propagation The strength with porosity is in the desired range for medical active implants, so, it is suitable for applications need tissue regeneration and growth [22].

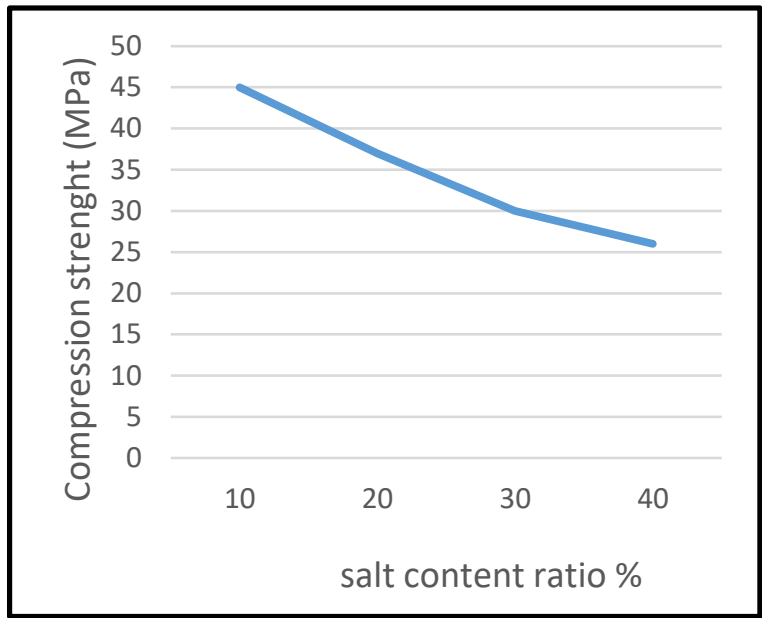

Fig. 7 Effect of the salt content on compression test of Ti samples.

\section{4 . Evaluation of toxicological and cell structure}

\section{adhesion by the in- vitro method}

Toxicological and cell structure adhesion were evaluated via in-Vitro method. Cytotoxicity recording cell morphological changes over the sample. Evaluation of free radicals effect on the normal cell compared with that viability of cell in control, showed a high viability percentage for all concentrations. So, Results showed no toxic effect on the life cells. The samples were safe as known in previous work $[23,24,25]$. It is noticed that cells in the medium around the $\mathrm{Ti}$ foam samples are more than that on the surface of samples. This may be due to sample charge that repeals cells out of the $\mathrm{Ti}$ surface and causes poor adhesion with titanium material [26]. Fig. 8 shows that Ti-10 to $40 \%$ salt sample has the highest cell validity with the highest cell concentration. In which, the porous structure and nano Ti particles, help in the viability of life cells on the Ti surface samples.

\subsection{Cell Morphology}

Scanning electron microscope of the life cells on the prepared Ti-foam shows a good viability on sample as shown in Fig 9. The growth was high in all samples with short term adhesion, due to the foam structure and the nano Ti particles. High proliferation was detected through the incubation period $24 \mathrm{~h}$ and $72 \mathrm{~h}$, but at the end it is found that low adhesion ratio of cells on samples. It is probably due to charge on the metal surface. In previous works, it was reported that Ti has low adhesion and need surface modifications and treatments to improve the adhesion between the cells and Ti sample's surface. 


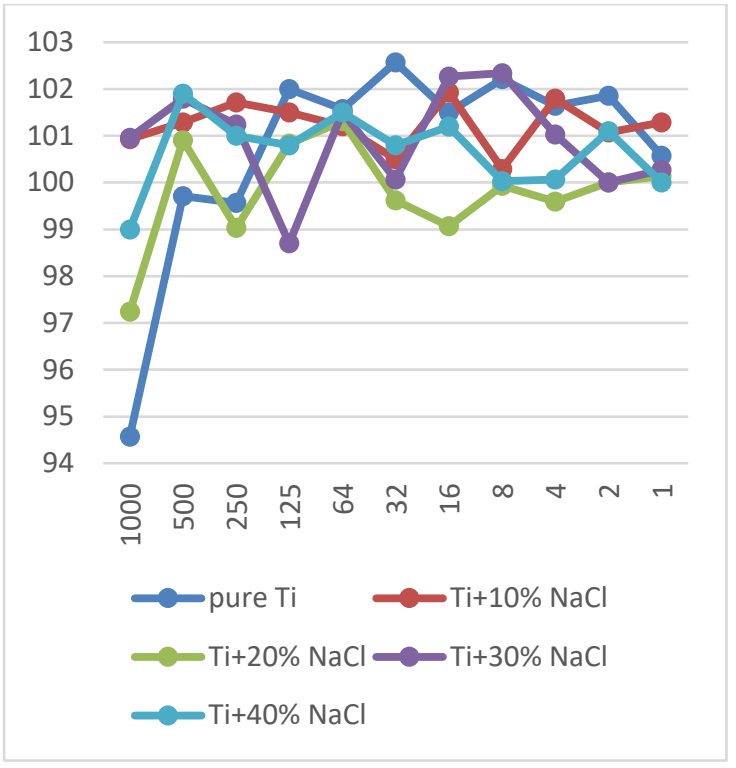

Fig. 8 Correlation between HFB4 concentration and the cell viability over Ti samples and Ti-10 to $40 \%$ salt after 2days culture.

This is in a trial to decreases the charges that repeat the life cells from the Ti foam surface. It is clear that addition of salt produces more porosity. This porosity increases the adhesion and growing of live cells on the sample surface. This can be explained by the good distribution of cells in the samples surface with the presence of low adhesion. Porosity with different ratios facilitates the adhesion and growth of cells. These results are compatible with the high hardness of $10 \%$ $\mathrm{NaCl}$ ratio sample. It is demonstrated that porous titanium implant could be used as an implant for various orthopaedic application. Surface treatment and plasma discharge are needed to be done for the fabricated samples and further studies are needed to be controlled.

\section{Conclusions}

- Ti has high melting point, high thermal stability, high strength and low density. So, Ti-foam is suitable for medical applications.

- The mechanical properties of titanium samples are improved by decreasing salt ratio.

- The hardness of pure titanium was increased by decreasing salt ratio, it was within the desired range required for medical applications.

- Samples have no toxic effect on cells but, it doesnot allow cells to adhere well on sample's surface and differentiate due to charges of surface.

- Ti with $10 \%$ salt has the highest hardness with low adhesion. while, Ti with $40 \%$ salt has the lowest hardness with highest adhesion. It could be used nano metal particles for mechanical reinforcement

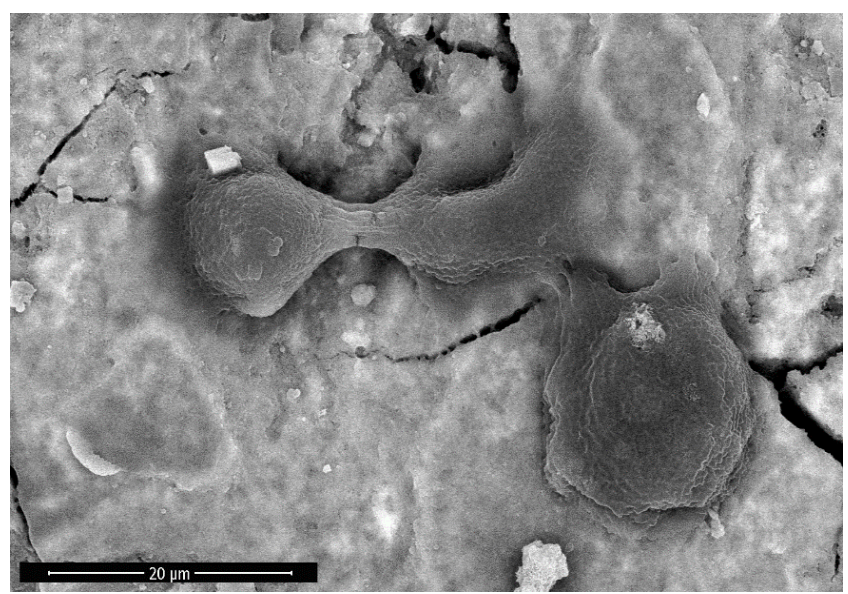

Fig. 9 SEM micrograph of cell cultured over Ti- 40\% implant with low cell distribution.

and surface treatment or coating should be done to encourage the cell to adhere and differntiate on surface of implant.

- Porous titanium implant could be used as an implants for various orthopedic applications.

\section{References}

[1] Q. Chen, GA. Thouas. Metallic implant biomaterials, Materials Science and Engineering, 87 (2015) 1-57, doi: 10.1016/j.mser.2014.10.001.

[2] K. Shemtov-Yona and D. Ritter. On the mechanical integrity of retrieved dental implants, J. Mech. Behav. Biomed. Mater: Rep., 49 (2015) 290-299. doi; 10.1016/j.jmbbm.2015.05.014.

[3] K.J. Franz and A.F. Hehmeyer. Introduction: Metals in Medicine, Chem. Rev. 119(2019) 727-729, DOI: $10.1021 /$ acs.chemrev.8b00685

[4] K. Dabrowia, .C. James . Metals in Medicine, Inorganic Chemica Acta. 393(2012) 1-2, doi.10.1016/j.ica.2012.07.022.

[5] I. Gotman. Characteristics of Metals Used in Implants, Journal of Endourology, 11(1998) 383389, doi: 10.1089/end.1997.11. 383.

[6] J. M. Calderon-Moreno et al. Microstructural and mechanical properties, surface and electrochemical characterization of a new Ti--Zr-$\mathrm{Nb}$ alloy for implant applications, Journal of Alloys and Compounds, 612(2014) 398-410, doi: 10.1016/j.jallcom.2014.05.159

[7] A.D. Marter, A.S. Dickinson, F. Pierron, et al. A Practical Procedure for Measuring the Stiffness of Foam like Materials, Experimental Techniques 42 (2018) 439-452, doi. 10.1007/s40799-018-0247-0

[8] S S Sharma, Y S Rajpoot. Development of aluminum metal foam using blowing agent, IOP Conference Series: Materials Science and 
Engineering, 377 (2018), doi:10.1088/1757899X/377/1/012150.

[9] S. Ahmad, N. Muhamad, J. Sahari, et al. Characterisation of Titanium Foams Sintered at Different Temperatures Prepared by the Slurry Method, Sains Malaysiana; Journal, 39 (2010) 77 82.

[10] M. Geetha, A. K. Singh, R. Asoka Mani, and A. K. Gogia. Ti based biomaterials, the ultimate choice for orthopedic implants--a review, Prog. Mater. Sci., 54 (2009) 397-425, doi: 10.1016/j.pmatsci.2008.06.004.

[11] A. Chouhan, Synthesis and Characterization of Tifoam using $\mathrm{NaCl}$ as space holder, Department of Biotechnology \& Medical Engineering, National Institute of Technology Rourkela, 2015.

[12] CE WEN. Novel titanium foam for bone tissue engineering, Journal of Materials Research, 17(2002) $2633 \quad-\quad 2639, \quad$ doi. 10.1557/JMR.2002.0382.

[13] Y. xuezheng. Mechanical Properties of Titanium Foams Having Disordered and Ordered Cell Structures, Tokyo Metropolition University, 2017.

[14] I. Braceras, J.I.Onate, L.Goikoetxea, J.L.Viviente, J.I.Alava, and M.A.de Maeztu, Bone cell adhesion on ion implanted titanium alloys, Surface and Coatings Technology journal. 196 (2005) 321-32, doi. 10.1016/j.surfcoat.2004.08.201

[15] A. R. Selfridge. Approximate material properties in isotropic materials, IEEE Xplore, 32(1985) 381-394, doi. 10.1109/ T-SU.1985.31608.

[16] M. Giner, E. Chicardi, A. Costa. Et al; Biocompatibility and Cellular Behavior of TiNbTa Alloy with Adapted Rigidity for the Replacement of Bone Tissue, Metals, MDPI, 130 (2021) 1-14. doi. 10.3390/met110101302021.

[17] A.A. Khalili and M.R. Ahmad. A Review of Cell Adhesion Studies for Biomedical and Biological Applications, Int. J. Mol. Sci. 16(2015) 1814918184, doi: 10.3390 / ijms160818149

[18] O. El-Kady, and A. Fathy. Effect of SiC particle size on the physical and mechanical properties of extruded Al matrix Nano composites, Materials \& Design, 54(2014) 348-353, doi /10.1016/j.matdes.2013.08.049

[19] A. Manonukul . P. Srikudvien and M. Tange, Microstructure and Mechanical Properties of Commercially Pure Titanium Foam with Varied Cell Size Fabricated by Replica Impregnation Method, Materials Science \& Engineering A. 650(2016) $432-437$ .doi.10.1016/j.msea.2015.10.074.
[20] M. E. Dizlek, M. Guden, et al. Processing and compression testing of Ti6Al4V foams for biomedical applications, Journal of Materials Science, 44(2009) 1512-1519, doi $10.1007 / \mathrm{s} 10853-008-3038-7$

[21] M.Y. Zakaria, M.I. Ramli, A.B. Sulong, N.Muhamad, M.H. Ismail. Application of sodium chloride as space holder for powder injection molding of alloy Titanium- Hydroxyapatite composites, Journal of Materials Research and Technology, 12(2021) 478-482, doi. 10.1016/j.jmrt.2021.02.087.

[22] T. Matsushit. S. Fujibayash. T. Kokubo, Titanium foam for bone tissue engineering, Metallic Foam Bone. 11(2017) 111-130, doi.10.1016/B978-0-08101289-5.00004-4.

[23] S. Kaur, K. Ghadirinejad and R.H. Oskouei, An Overview on the Tribological Performance of Titanium Alloys with Surface Modifications for Biomedical Applications, lubricants 65 (2019) 115, doi: 10.3390/ lubricants7080065.

[24] J.W. Nicholson. Titanium Alloys for Dental Implants: A Review, prosthesis, MPDI, 2(2020) 100-116; doi: 10.3390/ prosthesis2020011.

[25] D. P. Mondal, M. Patel, S.Das, A.K.Jha, G.Gupt, S.B.Ary, Titanium foam with coarser cell size and wide range of porosity using different types of evaporative space holders through powder metallurgy, Materials \& Design, 63 (2014) 89-99, doi. 10.1016/ j. matdes.2014.05.054

[26] O. Cetinel, Z. Esen and B. Yildirim. Fabrication, Morphology Analysis, and Mechanical Properties of Ti Foams Manufactured Using the Space Holder Method for Bone Substitute Materials, Metals, MDPI, 9-340(2019); doi: 10.3390/ met9030340 